Division of Geological \& Geophysical Surveys

RAW-DATA FILE 2016-6

\title{
MAJOR-OXIDE, MINOR-OXIDE, AND TRACE-ELEMENT GEOCHEMICAL DATA FROM ROCKS COLLECTED IN 2008 IN THE EASTERN BONNIFIELD MINING DISTRICT, FAIRBANKS AND HEALY QUADRANGLES, ALASKA
}

by

Larry K. Freeman, Rainer J. Newberry, Alicja Wypych, Melanie B. Werdon, David J. Szumigala, Joseph E. Andrew, and Jennifer E. Athey

$\$ 2.00$

April 2016

THIS REPORT HAS NOT BEEN REVIEWED FOR

TECHNICAL CONTENT OR FOR CONFORMITY TO THE

EDITORIAL STANDARDS OF DGGS

Released by

STATE OF ALASKA

DEPARTMENT OF NATURAL RESOURCES

Division of Geological \& Geophysical Surveys

3354 College Road

Fairbanks, Alaska 99709-3707 


\title{
MAJOR-OXIDE, MINOR-OXIDE, AND TRACE-ELEMENT GEOCHEMICAL DATA FROM ROCKS COLLECTED IN 2008 IN THE EASTERN BONNIFIELD MINING DISTRICT, FAIRBANKS AND HEALY QUADRANGLES, ALASKA
}

\author{
by \\ Lawrence K. Freeman ${ }^{1}$, Rainer J. Newberry ${ }^{2}$, Alicja Wypych ${ }^{1}$, Melanie B. Werdon ${ }^{1}$, \\ David J. Szumigala ${ }^{3}$, Joseph E. Andrew ${ }^{4}$, and Jennifer E. Athey ${ }^{1}$
}

\section{INTRODUCTION}

Mineral-resources personnel from the Alaska Division of Geological \& Geophysical Surveys carried out a geological field survey, including mapping and sampling, in the eastern part of the Bonnifield mining district in the Fairbanks A-1 and A-2, and the Healy D-1 and D-2 quadrangles, Alaska, from June 16 through July 18, 2008. The fieldwork provides basic information critical to building an understanding of Alaska's geology and is part of an integrated program of airborne geophysical surveys followed by geological mapping. Specifically, this work provides geologic context for geophysical surveys conducted in 2006 (Burns, and others, 2016). To represent a typical lithology, 539 igneous or possible meta-igneous samples were collected and analyzed for major- and minor-oxide and petrogenetically important trace elements as a supplement to previously published geochemical data (Freeman and others, 2009). The analyses were used to determine composition of the samples as well as potential original tectonic setting. Radiometric age analyses from some of these rocks have been published (Benowitz, and others, 2011). Interpretation and synthesis of this data has been presented in professional and trade meetings (Freeman, and others, 2013).

The analytical data tables associated with this report are available in digital format as comma-separated value (CSV) files. Additional details about the organization of information are noted the accompanying metadata file. All files can be downloaded from the DGGS website (doi:10.14509/29653).

\section{DOCUMENTATION OF METHODS}

\section{SAMPLE COLLECTION}

The rocks were collected in a random distribution throughout the study area. Location coordinates were derived using hand-held Garmin GPS 12xl GPS units (no differential correction was applied). Estimated position errors calculated by the hand-held GPS were a minimum of $3 \mathrm{~m}$; at many locations the horizon was limited by steep topography, resulting in positional errors of more than $100 \mathrm{~m}$. Coordinates were downloaded to an MS Access database, and sample analyses were programmatically matched to location and field description data using sample numbers. These matches were hand checked against labels on the slabs while processing and synthesizing the data. Coordinates are presented in latitude and longitude (based on the NAD 27 Alaska datum).

\footnotetext{
${ }^{1}$ Alaska Division of Geological \& Geophysical Surveys, 3354 College Road, Fairbanks, AK 99709-3707; lawrence.freeman@alaska.gov

${ }^{2}$ Department of Geosciences, University of Alaska Fairbanks, P.O. Box 755780, Fairbanks, Alaska $99775-5780$

${ }^{3}$ Alaska Division of Geological \& Geophysical Surveys, 3354 College Road, Fairbanks, AK 99709-3707, now at djszumigala@gmail.com

${ }^{4}$ Alaska Division of Geological \& Geophysical Surveys, 3354 College Road, Fairbanks, AK 99709-3707; now at Department of Geology, University of Kansas, 2335 Irving Hill Road, Lawrence, KS 66045
} 


\section{SAMPle Preparation}

For this study the rocks were cut using a diamond-blade tile saw; foliated and lineated rocks were cut so that the analyzed surface is at right angles to the rock fabric. Surfaces for analysis were lightly polished with a lapidary wheel to provide a smooth surface to minimize X-ray scatter.

\section{ANALYTiCal MethodS}

X-ray florescence (XRF) spectroscopic analyses were performed at UAF using a PANalytical Axios spectrometer under vacuum. The measurements were standardized using well-characterized, natural, fine-grained rock and pure mineral standards as well as conventional pressed pellets of international rock standards. Because no volatile components were measured and rocks were of varying porosities, the analyses were normalized to 100 percent totals. In the vast majority of cases the original analyses yielded totals of approximately 95 to 102 weight percent. Comparison between these analyses and those produced on the same rocks by conventional pressed pellet (for trace elements) and fused disk (for major and minor oxides) techniques indicates that major- and minor-oxide and traceelement concentrations are most likely within 10 percent of the 'true' concentrations.

\section{DISCUSSION}

The analytical results were used to assign unit names for a geologic map that is in preparation. Preliminary interpretation (Freeman and others, 2009) subdivided the rocks into four major groups of metamorphic rocks and three groups of unmetamorphosed igneous rocks. Rock names, both field names based on hand-specimen observation and names based on the geochemical classification, as well as textural observations in polished slabs are presented in the data table as an aid for the user. The main metamorphic rock classifications use immobile element ratios (Winchester and Floyd, 1977) and absolute values of yttrium, niobium, and zircon. Nomenclature of Mystic Creek Member and California Creek Member is adopted from prior work (Warhaftig, 1968; Dusel-Bacon and others, 2004); rocks of the Mystic Creek Member are peralkaline metarhyolites or metasediments derived from peralkaline rhyolites with high niobium, yttrium, and zirconium values, whereas rocks from the California Creek Member are metarhyodacites or metasediments derived from rhyodacites and have lower niobium, yttrium, and zirconium values (Freeman and others, 2013).

\section{ACKNOWLEDGMENTS}

This project is part of the Alaska Airborne Geophysical/Geological Mineral Inventory Program funded by the Alaska State Legislature and managed by the State of Alaska, Department of Natural Resources, Division of Geological \& Geophysical Surveys. Partial funding for the geologic mapping and geochemical analyses was also provided through the State of Alaska General Fund and the U.S. Geological Survey STATEMAP Program under award number 08HQAG0051.

\section{REFERENCES}

Benowitz, J.A., Layer, P.W., and Freeman, L.K., 2011, ${ }^{40} \mathrm{Ar} /{ }^{39} \mathrm{Ar}$ Ages from the east Bonnifield geologic map area, Fairbanks A-1, Fairbanks A-2, Healy D-1, and Healy D-2 quadrangles, Alaska: Alaska Division of Geological \& Geophysical Surveys Raw Data File 2011-2, 22 p. doi:10.14509/22482

Burns, L.E., Fugro Airborne Surveys Corp., Stevens Exploration Management Corp., Graham, G.R.C., and Emond, A.M., 2016, Bonnifield mining district electromagnetic and magnetic airborne geophysical survey, data compilation: Alaska Division of Geological \& Geophysical Surveys Geophysical Report 2016-1. doi: $\underline{10.14509 / 29557}$

Dusel-Bacon, Cynthia, Wooden, J.L., and Hopkins, M.J., 2004, U-Pb zircon and geochemical evidence for bimodal mid-Paleozoic magmatism and syngenetic base metal mineralization in the Yukon-Tanana terrane, Alaska: Geological Society of America Bulletin, v. 32, p. 989-1,015. 
Freeman, L.K., Newberry, R.J., Andrew, J.E., Szumigala, D.J., Werdon, M.B., Athey, J.E., and Burns, L.E., 2013, Geologic setting of syngenetic and epigenetic deposits in the eastern Bonnifield mining district, Alaska [presentation]: Alaska Miners Association, 22nd Annual Biennial Mining Conference, March 9-13, 2010: Alaska Division of Geological \& Geophysical Surveys, 25 p. doi:10.14509/25279

Freeman, L.K., Werdon, M.B., Szumigala, D.J., Andrew, J.E., Newberry, R.J., and Athey, J.E., 2009, Geochemical, major-oxide, minor-oxide, trace-element and carbon data from rocks collected in 2008 in the eastern Bonnifield mining district, Fairbanks and Healy quadrangles, Alaska: Alaska Division of Geological \& Geophysical Surveys Raw Data File 2009-1, 69 p. doi:10.14509/20041

Wahrhaftig, Clyde, 1968, Schists of the central Alaska Range: U.S. Geological Survey Bulletin 1254-E, p. E1E22.

Winchester, J.A., and Floyd, P.A., 1977, Geochemical discrimination of different magma series and their differentiation products using immobile elements: Chemical Geology, v. 20, p. 325-343. 